\title{
Major Power Intervention in International Crises, 1918-1988
}

\author{
PAUL K. HUTH \\ Institute for Social Research \\ University of Michigan
}

The author tests a set of hypotheses about the conditions under which major powers intervene with military support for states that are threatened in a crisis. The hypotheses are derived from a general theoretical approach that integrates a realist framework with recent works that focus on the domestic political determinants of foreign policy. Seven of the eight hypotheses tested are supported by the results of logit analysis on major power interventions in 272 international crises from 1918 to 1988. The broad theoretical implication is that scholars drawing on realist approaches to studying international politics should think rigorously about the role of domestic politics in foreign policy decisions.

The military intervention of major powers can have a decisive impact on the outcome of international crises involving other states. Such interventions have deterred the outbreak of war (Huth 1988) and have led to the military defeat of aggressors when policies of extended deterrence have failed (Wang and Ray 1994; Gartner and Siverson 1996; Stam 1996, chaps. 5-6). Challengers to the status quo want to avoid military escalation when major powers are expected to intervene in support of their adversaries, and defending states seek outside support to counter threats to their security. Miscalculation by either side can have far-reaching security consequences. State leaders may engage their country in military hostilities with a stronger military coalition if they underestimate the likelihood of intervention by major powers. Conversely, policy makers from defending states may stand firm in crisis negotiations only to find that, at the brink of war, a major power does not come to their defense as expected.

In the post-cold war era, the question of major power intervention remains central to understanding patterns of escalation by challenger states and the outcomes to regional conflicts. Consider, for example, the history of repeated threats and then North Atlantic Treaty Organization (NATO) intervention with air power in 1995 against the Serbs in the Bosnian conflict (Gow 1997). In the Middle East, the Iraqi attempt to

AUTHOR'S NOTE: I thank the National Science Foundation for its financial support of this research. The excellent research assistant work of John Squier is greatly appreciated. My thanks also to Chris Achen, Doug Lemke, and Eleni Eletheriou for their helpful comments on earlier drafts of this article. The data set used in this article is available from the author upon request.

JOURNAL OF CONFLICT RESOLUTION, Vol. 42 No. 6, December 1998 744-770

(C) 1998 Sage Publications, Inc. 
overrun Kuwait in 1990 was turned back by a U.S. military counterintervention (Freedman and Karsh 1993), and in the Far East, Chinese opposition to Taiwanese independence risks U.S. intervention, which would transform this bilateral dispute over self-determination into a larger U.S.-Sino crisis (Freeman 1998).

My objective in this article is to advance our understanding of when the leaders of major powers will decide to intervene with the threat or use of military force in international crises to defend states threatened with attack. The larger theoretical and empirical contribution of this study is directed at the question of when states will pursue policies that are likely to lead to attempts at extended deterrence. The literature on deterrence is oriented toward explaining when policies of deterrence succeed or fail. As a result, we do not have a well-established body of scholarly work that explains when state leaders actually intervene and support an ally with deterrent policies. In this article, I address this gap in the literature. ${ }^{1}$

The article is divided into the following sections. First, I outline a rational choice approach to studying foreign policy choices that integrates realist and domestic politics models, and then I present a series of testable hypotheses. Second, I describe the research design employed and the data set of 272 international crises used for the empirical tests. Third, I report the results of the statistical analysis and discuss the implications for the hypotheses tested. In the conclusion, I discuss areas for future research.

One central underlying argument that $I$ present in this article is that a realist approach to analyzing international politics can be strengthened by theorizing about how the domestic political concerns of state leaders may have systematic and consequential effects on their foreign policy decisions. The incorporation of domestic politics into a realist approach broadens our understanding of how foreign policy leaders define the issues at stake in international crises and what power resources they may have available for military conflicts abroad. A second crucial theoretical argument is that the strategic rationale and risks of military conflict, which are integral to a realist approach, are often intertwined with the domestic political viability of foreign policy decisions to threaten or use military force. In other words, from the perspective of a realist approach, what seems like a rational decision regarding intervention depends also on foreign policy leaders being able to "sell" such a policy to important domestic political constituencies.

\section{THEORETICAL APPROACH}

Whether to intervene in an ongoing international crisis can be a risky foreign policy choice for state leaders. The risks can be high because of uncertainty about the outcome and costs of a military engagement, the degree of domestic political support for military operations abroad, and the international and domestic political costs of failing

1. Studies exist on related questions such as third-party patterns of alignment in ongoing wars and militarized disputes (e.g., Altfeld and Bueno de Mesquita 1979; Siverson and Starr 1991; Werner and Lemke 1997) as well as alliance formation (e.g., Walt 1987; Morrow 1993). I will draw on these literatures to develop my argument and compare my results with existing findings. 
to extend full support to another state. ${ }^{2}$ The theoretical question, then, is what set of domestic and international conditions produce acceptable military and political risks of intervention and thus convince leaders that military involvement in a dispute will lead to favorable domestic and foreign policy outcomes?

What factors determine not only the willingness of major powers to take a clear diplomatic stand in support of a threatened state but also to undertake, if necessary, extensive military actions? State leaders are disinclined to assume the risks of military intervention abroad. In the Correlates of War (COW) data set on militarized interstate disputes between 1816 and 1988, more than $80 \%$ of the disputes short of war are bilateral, whereas about 65\% of the interstate wars are bilateral (Jones 1994, 243).

In my theoretical framework, state leaders are rational foreign policy decision makers who seek to remain in power, but they are also concerned with promoting the international security of their country and are therefore careful to pursue security policies that do not undermine their domestic political position. In this modified realist framework, both domestic political concerns and international power considerations determine foreign policy choices (see Huth 1996, chap. 3). Below I present a series of hypotheses in which I try to develop logical connections between domestic politics and security policy in three ways.

First, I argue that state leaders need to balance the pursuit of security interests abroad with the domestic politics of building a coalition of political support behind a decision to intervene. This line of argument provides supporting logic for hypotheses $1,2,3$, and 6 and posits that foreign policy leaders seek to manage domestic opposition from two different sources: those groups that are pragmatically supportive of military intervention abroad and those that are more isolationist and skeptical of military actions intended to support other states. Pragmatic intervenors will generally defer to executive leadership and initiative in security policy, but they will hold leaders accountable for the outcomes of military actions and respond by punishing leaders for failed intervention outcomes. Isolationist critics are wary of risking lives and expending financial resources to support allies, tend to resist broad definitions of national security interests, and are less willing to defer to agenda setting in security policy by the central leadership. As a result, isolationist critics are more likely to contest a government's rationale for military intervention and demand clear justification for risking military conflict. The result is that, in making decisions about military intervention, leaders will try to protect themselves against opposition from each of these sources.

Second, a leader's desire to hold onto power can create incentives to pursue foreign policies that the leader believes will enhance his or her domestic political position. Foreign policy can then, in part, be understood as a means for achieving domestic political security. Hypotheses 7 and 8, in particular, draw on this logic. The domestic political needs of leaders can help define what issues are at stake in international

2. The argument that state leaders risk domestic political costs for failing to act more forcefully is another line of argument (e.g., Fearon 1994a, 1997) but will not be the focus of theoretical analysis in this article. Instead, I will concentrate on the domestic political costs or benefits of pursuing a more forceful policy of intervention in international disputes. 
disputes and therefore what goals they may seek to advance by intervening in international crises.

Third, the simultaneous pursuit by state leaders of domestic political and international security may create potential trade-offs between the resources (financial, manpower, time) available to governments to support both sets of goals. If the resource constraints become acute enough, the domestic political needs of leaders may force them to forego a more active foreign policy. Thus, the high priority attached by leaders to domestic political survival may limit at times the military and diplomatic resources that foreign policy leaders are willing to commit to international disputes. The logic supporting hypothesis 5 most directly reflects this line of argument.

The hypotheses developed from this modified realist approach focus on two sets of factors that should figure centrally in the calculations of state leaders: (1) the likely military and political costs and risks of intervention and (2) the domestic and international security benefits associated with supporting a country threatened with attack. The contribution of this modified realist approach is to broaden a conventional realist analysis by thinking systematically about what are the domestic political bases of support and opposition to national security policies, how domestic political conditions can affect the relative military strength of states, and how the desire to retain power domestically affects leaders' assessments of security threats and what issues are at stake in international disputes.

The first two hypotheses focus on the military need for intervention. The supporting logic draws on both a conventional realist approach and a domestic level of analysis in which the domestic opposition of potential isolationist critics is considered:

Hypothesis 1: The probability of military intervention by a major power will decrease as the capacity of a threatened state to defend itself militarily increases.

Hypothesis 2: The probability of military intervention by a major power will increase as the severity of the threat of military attack against a target state increases.

Although it might seem intuitive to argue that leaders would seek to minimize the risks associated with intervention, the first two hypotheses argue that without some degree of military danger, there would be no compelling security rationale for forceful intervention. The logic of hypothesis 1 is that the leaders of major powers should be selective in their decisions to intervene, or they risk provoking dissension from isolationist critics who could argue that intervention is not justified and overextends what limited military commitments the country should assume. Overextension, in turn, could weaken the country's capacity to defend vital security interests and induce other states to form opposing coalitions.

The leaders of major powers should therefore avoid military interventions when threatened states have the military capabilities to counter a military challenge. To intervene in such cases would divert military forces to a conflict in which they are not required. Instead, leaders should be more likely to remain uninvolved or limit support to diplomatic actions. Major powers then should target for military support those states that are in a weak military position to defend themselves in an armed conflict. 
The second hypothesis builds on the logic supporting hypothesis 1 . In addition to assessing how militarily self-sufficient the target state is, the leaders of major powers should also evaluate how threatening the policies are of the challenger state. Intervention should be likely when there are pressing security threats to another state. The larger and more imminent the threat of attack, the more persuasive is the argument that another state is confronted with a security threat that requires intervention to counter. Major power leaders are often interested in the outcomes of conflicts involving other states, but priorities need to be established as to when intervention is justified.

Major powers need to justify intervention from both a strategic and domestic politics perspective. A credible argument for intervention is important because leaders will need to explain why military action is necessary to key domestic political constituencies (e.g., Politburo members, military leaders, and leaders of political parties). If foreign policy leaders can present a strong case for why the target state requires military support, this should help them counter political opposition to a policy of intervention by enabling them to confront domestic opposition with charges of undermining the national security of their own country and that of allies (see also Nincic 1997). The argument then is that a decision to intervene is more likely to receive domestic support when an ally is confronted with pressing military threats.

The first two hypotheses posit that a higher risk of a military defeat of a prospective ally increases the chances of intervention. The next hypothesis focuses on whether military intervention by the major power can offset such risks and therefore counter potential opposition from pragmatic intervenors. As with the first two hypotheses, I attempt to integrate domestic politics into an argument in which a realist approach provides the logical foundation:

Hypothesis 3: The probability of intervention by a major power will increase as the relative military strength of the coalition supporting the threatened state increases.

Although the military weakness of the threatened state should create a perceived need for intervention, state leaders should not intervene unless they can overcome the military weakness of their prospective ally. Forceful actions should be more likely when leaders are confident of a successful military or diplomatic outcome to a crisis following intervention. Political leaders want to avoid interventions that carry heightened domestic political risks due to diplomatic or military setbacks. ${ }^{3}$ It follows that a successful intervention is more likely as the relative military capabilities of the states that intervene increase. The stronger the major power and supporting allies, the higher the probability of the major power using its military advantage to deter an attack and to pressure the attacker either to make concessions in negotiations or successfully repulse an attack if deterrence fails.

If the coalition supporting the challenger, however, has a military advantage, then the challenger is more likely to resist making concessions and to use military force to overturn the status quo and defeat the defender in an armed conflict. If the major power

3. It is important to note that military setbacks for any government (democratic or nondemocratic) significantly increase the risks of the current leadership being removed from power (Bueno de Mesquita, Siverson, and Woller 1992; Bueno de Mesquita and Siverson 1995). 
cannot compensate for the military weakness of its ally, it risks a foreign policy setback from an unfavorable diplomatic settlement or a failure of deterrence and the ally's defeat in war. In either case, political opposition within the major power may blame the leadership for pursuing failed policies and seek to remove the leaders from power (Aldrich, Sullivan, and Borgida 1989; Brace and Hinckley 1992; Bueno de Mesquita, Siverson, and Woller 1992; Bueno de Mesquita and Siverson 1995; Marra, Ostrom, and Simon 1990; Nincic and Hinckley 1991).

The next two hypotheses consider potential domestic and international constraints on the military capabilities that are available to major power leaders for intervention:

Hypothesis 4: The probability of intervention by a major power will decrease if leaders of the major power are about to or have already committed large-scale military forces to another international dispute.

Hypothesis 5: The probability of intervention by a major power will decrease if leaders of the major power are about to or have already committed large-scale military forces to the suppression of domestic political opposition.

Hypothesis 4 follows quite directly from a realist approach in which relative military power is considered to be a central determinant of a state's capacity to achieve its diplomatic and military goals in disputes with other states. Although major powers are defined in part by their greater military capabilities compared to most other states, their military leaders nevertheless should be sensitive to problems of committing military forces to multiple theaters simultaneously. As a result, if the armed forces of a major power have already been committed to another armed conflict at the time an international crisis erupts involving other states, we would expect political leaders to receive conservative advice from the military leadership about the desirability of military intervention.

Hypothesis 5 extends this basic logic further and argues that when domestic political opposition has become so strong and threatening that state leaders feel it is necessary to commit large numbers of their regular armed forces to political suppression, this should weaken the country's capacity for external military operations. As a result, the major power's relative military strength should be discounted to reflect the diversion of some of its military forces to internal security needs. It is quite unlikely that the suppression of coups, armed insurgencies, or even the outbreak of civil war will cripple a major power's military capacity to intervene abroad. Nevertheless, it would seem preferable for state leaders to accept the risks of international military conflict when their armed forces are fully available to meet any external contingencies instead of being at least partially tied down due to severe domestic political problems.

The next two hypotheses consider the potential domestic and international security benefits of intervention:

Hypothesis 6: The probability of intervention by a major power will increase if the threatened state is of military-strategic value to the major power.

Hypothesis 7: The probability of intervention by a major power will increase if the major power and threatened state share the same type of political system that differs from the regime of the challenger state. 
The logic of hypothesis 6 begins with the conventional realist premise that the strategic value of a state is critical in determining whether important security interests are at stake in supporting that state in an international dispute. The strategic value of states can be determined by their ties of military cooperation with a major power, the presence of a common adversary between the two states, or a state's close proximity to territory that is of military importance to a major power. In each case, the leaders of major powers are likely to believe that important security interests are at stake in supporting an ally. For example, military cooperation between states includes the formation of alliance ties, the provision of weapons through arms transfers, or the use of national territory for military bases or intelligence gathering. These types of ties could indicate either the value of a state in supporting the security interests of a major power or the importance that a major power attaches to the security of the allied state itself. In addition, if a strategically located state were to adopt hostile defense policies, this could put at risk the major power's ability to project its military forces and to defend its allies. Finally, if the threatened state and major power are both locked in disputes with a common adversary, then the major power could expect greater diplomatic and perhaps even military support from the threatened state because these two states would have stronger incentives to coordinate their foreign policies.

When these types of military ties and common security interests exist between the threatened state and the major power, a combination of direct and indirect security issues is likely to be at stake for the major power. For example, the failure of the major power to intervene could place at risk future access to military bases, the willingness of the recipient country to pursue common foreign policy goals, or raise larger questions about the credibility of the major power's other alliance obligations (see also Fearon 1997).

When these types of military security issues are at stake, foreign policy leaders should be in a stronger domestic political position to build a coalition in support of intervention. As already argued, political leaders should be more inclined to intervene if they can present a credible argument that security interests are at stake in supporting a threatened state. Thus, we would expect that if the threatened state is of strategic value, then leaders could more effectively justify intervention and challenge the counterclaims of domestic political opponents who might favor a more isolationist policy. ${ }^{4}$

Whereas hypothesis 6 focuses on various forms of military ties and cooperation as the foundation for assessing security issues at stake, hypothesis 7 addresses the domestic political basis of assessing the security issues at stake. The logic of hypothesis 7 starts with the recognition that major power leaders are concerned with protecting their domestic political power while seeking to enhance their country's external security. One central concern for leaders when they are considering intervention, then, is whether they expect the threatened state to pursue foreign policies that are likely to challenge its domestic or international security interests.

4. Conversely, the failure to support a strategic ally might expose the political leadership to higher domestic audience costs as the political opposition challenges the government's policy of inaction. 
The argument is that leaders from states that share common political institutions and ideologies are less likely to view one another as security threats because they share common interests in preserving political stability at home that, in turn, should lead these states to adopt less conflictual foreign policies toward one another. The legitimacy and survival of regimes at home can be enhanced by political allies abroad supporting one another. For example, studies report that breakdowns of democracy are associated with few democratic neighbors, but successful transitions to democracy and their long-term survival are associated with higher numbers of democratic neighbors (Przeworski et al. 1996; Gasiorowski 1995). Furthermore, attempts to overthrow the regimes of foreign countries following wars are more likely when the war combatants are politically dissimilar (see Werner 1996; Bueno de Mesquita and Siverson 1997).

As noted, diplomatic and/or military defeats often generate a heightened risk that domestic political opposition will arise that can challenge not only government policies but the existence of the regime itself. Thus, state leaders who share similar domestic political institutions and ideologies have an incentive to adopt more compatible and cooperative security policies to avoid acute international conflicts that could increase domestic political instability for their political ally. This may help explain why political allies are less likely to become involved in militarized disputes as adversaries and are more likely to support one another against other states in such disputes (Oneal and Russett 1997; Mousseau 1997; Werner and Lemke 1997). State leaders then should have a political interest in preventing political allies abroad from suffering major foreign policy defeats because domestic political instability within the defeated ally runs some risk of weakening political authority and legitimacy within one's own country and because political allies are expected to pursue more favorable security policies.

The final hypothesis considers the potential domestic political risks of intervention by leaders of democratic major powers:

Hypothesis 8: The probability of intervention by a major power will decrease if the incumbent regime's chances of victory in upcoming elections are quite favorable.

Hypothesis 8 draws on research that considers the impact of democratic elections on foreign policy behavior as well as incentives to engage in diversionary foreign policy actions (e.g., Smith 1996b; Smith and Hayes 1997; Downs and Rocke 1995; Gowa 1998; Morgan and Bickers 1992; Ostrom and Job 1986; Fearon 1994a; Bueno de Mesquita and Lalman 1990; Hagan 1993; Richards et al. 1993; Gaubatz 1991; James and Oneal 1991; Meernik 1994; Stoll 1984). According to the modified realist approach, foreign policy leaders are centrally concerned with retaining their positions of domestic political power. As a result, the desire to remain in office may cause political leaders to turn to foreign policy as a means to boost their domestic political standing. Military intervention in a crisis, however, is a risky policy, as noted already, and therefore such a policy should be expected only under limited conditions.

Specifically, when leaders face a possible defeat in upcoming elections, they then have political incentives to pursue a confrontational foreign policy in the hope that an 
international crisis will rally domestic support behind the government. The depth and duration of a rally effect, however, are related to whether intervention in a crisis is viewed as justified by counterelites and if it results in favorable diplomatic and/or military outcomes (Brace and Hinckley 1992; Russett 1990; Mueller 1994; Brody 1991; Lian and Oneal 1993; Smith 1996b; Smith and Hayes 1997). Thus, even when leaders have a relatively high demand for diversionary foreign policy actions, we would not necessarily expect them to pursue such actions in all instances. For political leaders who risk losing power in upcoming elections, the temptation to gamble on a foreign policy victory should be quite strong except for those leaders who are almost certain that they face electoral defeat. In contrast, when an incumbent leader's prospects for reelection are favorable, there is very little political incentive to risk intervention. In such circumstances, leaders should avoid intervention for fear that a diplomatic or military setback would jeopardize their likely victory in upcoming elections.

\section{RESEARCH DESIGN AND MEASUREMENT OF VARIABLES}

Between 1919 and 1988, 272 international crises were identified using the data set of Rousseau et al. (1996). Rousseau and coauthors revised the international crisis behavior (ICB) data set of Brecher and Wilkenfeld $(1988,1997)$ by (1) removing intrawar crises and crises in which strong evidence could not be identified for military actions taken by a challenger state, indicating a possible threat of force, and (2) merging some crises into single longer crises.

I accepted these changes in the ICB data set for the following reasons. First, intrawar cases were removed because my larger theoretical focus is on explaining when a state attempt extended deterrence, and thus I should remove conflicts that already have escalated to war because policies of extended deterrence are no longer possible. Second, the underlying assumptions of my analysis are that a state is confronted with a security threat and a major power must decide whether to support that state. Therefore, all cases were removed in which a military threat to a state could not be confirmed. Third, some disputes that were designated as multiple crises were merged into single cases because the diplomatic and military actions of the states involved were part of an ongoing conflict without clear and distinct breakpoints in the pattern of conflict behavior. As a result, I was concerned that these crises could not in fact be treated as independent observations in a statistical test. Therefore, I decided to merge them into a single crisis to reduce the risks of including nonindependent observations in the data set. The one additional change that I made was to exclude all crises in which a minor power was challenging a major power. I did so on the grounds that such crises were of limited theoretical interest because major power intervention was very unlikely given the expectation that a major power would not require military support in a dispute with a minor power. ${ }^{6}$

5. The deleted or merged cases are listed in Rousseau et al. $(1996,532)$.

6. Of the 29 cases removed for this reason, the major power target did not receive military support from another major power in a single case. 
For each crisis in the data set, I designated which state was the potential attacker and which state was threatened with attack. The potential attacker was coded as the first state to threaten or resort to the use of force, and the target of such military actions was coded as the threatened state. The label of attacker or target does not imply any judgment about the offensive or defensive goals of either state. In most cases, the attacker is associated with the state seeking to overturn the territorial status quo or destabilize a neighboring regime, but that is not always the case.

In those crises in which a major power intervened with either active diplomatic actions (27) or some level of military force in support of the target (72), that state was listed as the major power intervenor. In cases in which more than one major power intervened (10 cases), I consulted historical sources to determine which major power played a leadership role and intervened first in support of the target state. That state was then listed as the intervenor, and the other major powers were listed as additional allies. In crises in which no major power intervened diplomatically or militarily in support of the target (173 cases), I identified which major powers had remained uninvolved ( 830 in total). The next step was to select randomly for each crisis one of the major powers that was not involved. This major power was then listed as the potential major power intervenor. From the population of major powers that did not intervene in 173 crises, a random sample of $20.8 \%$ was selected (173/830).

The entire data set of 272 crises includes either a major power that did intervene ( 99 cases) or one that might have but did not (173 cases). The complete data set includes then the population of major powers that did intervene in support of targets with a random sample of major powers that did not intervene at all. This type of research design is known as a retrospective sampling design and is commonly used in clinical and public health studies. Such a design produces unbiased parameter estimates as long as a logit regression model is used to test hypotheses. The only correction required is that the constant estimated by the logit analysis must be adjusted to reflect that only a sample $(20.8 \%)$ of the major powers that did not intervene are actually included in the data set. The procedure is to take the log of the proportion of the sample selected (the log of $.208=-1.57$ ) and add that to the estimated constant produced by the logit equation. ${ }^{7}$ It is important to adjust the constant so that the number of correct predictions produced by the logit equation is accurately determined and the marginal effects of variables are accurately calculated as well.

I used a retrospective sampling design because it enabled me to construct more detailed measures for variables in a smaller sized data set. The advantage of this research design is that more sophisticated operational measures could be employed for several independent variables without biasing the generalizability of the statistical results. The practical alternative to the retrospective sampling design is to include all 830 great powers from the 173 nonintervention cases plus all great powers that did not intervene in the 99 cases in which some major powers did intervene (roughly 400 more

7. Two useful sources that discuss the retrospective sampling design are Agresti (1990, chaps. 2, 4) and Fleiss (1981, chap. 6). In Table 1, the corrected constant was determined by taking the originally estimated value of -6.96 and adding -1.57 . 
observations). Empirical tests on this data set of more than 1,200 cases would be limited to a few independent variables that could be measured by easily collectable data or drawn from preexisting data sets. The result would have been to increase greatly the amount of measurement error and to test a poorly specified model. Instead, I combined the population of major power intervenors with a random sample of nonintervenors. This more manageably sized data set allowed me to measure much more effectively the strategic value of the target- and domestic-level variables such as the electoral prospects of democratic major powers and the severity of periods of political unrest and armed conflict.

I focus on what scholars (e.g., Small and Singer 1982; Levy 1983) commonly refer to as major powers as the states that might intervene in an international crisis for two reasons: (1) they have the political and military capacity to project military forces beyond their immediate borders, and (2) they typically have security interests and military ties with states beyond their immediate borders. The implication is that the leaders of major powers are more inclined to define their country's national security interests in broader regional, if not global, terms and thus consider diplomatic and even military intervention in many international disputes. The result is that major powers, unlike many other states, potentially might intervene in any given crisis. Nevertheless, even major powers do not militarily intervene in most cases of international militarized disputes. The interesting question, then, is to explain the variation in the decisions of major power leaders to intervene. My focus on major powers, however, precludes generalizing to the population of all states due to problems of selection effects. I draw on widely used classifications (Small and Singer 1982; Levy 1983) to identify the following states as major powers: Soviet Union, 1919-1988; France, 1919-1988; Great Britain, 1919-1988; United States, 1919-1988; Japan, 1919-1945; Italy, 1919-1945; Germany, 1935-1945; and China, 1953-1988.

The following equation will be tested by logit analysis:

$$
y=c+b_{1} x_{1}+b_{2} x_{2}+b_{3} x_{3}+b_{4} x_{4}+b_{5} x_{5}+b_{6} x_{6}+b_{7} x_{7}+b_{8} x_{8}+b_{9} x_{9}+b_{10} x_{10}+u_{t} .
$$

The dependent variable $(y)$ is as follows: $y=$ the level of support that the major power intervenor provides to a state threatened with attack.

Adichotomous scale was used to measure the level of support provided by the major power: $0=$ no diplomatic/military support or only diplomatic support, and $1=$ limited or full military support. Diplomatic support was defined to include each of the following: (1) active political steps being taken by the major power to protest and criticize the actions of the challenger state, (2) public approval for the policies and position of the threatened state in the crisis, and (3) efforts to build a political coalition among other states that backed the position of the threatened state. Military actions by the major power included the movement, buildup, concentration, or placing of forces on alert in preparation for possible intervention directly against the challenger or the deployment of forces on the territory or in close proximity to the coastline of the threatened state. Limited military support occurred when the military actions of the major power failed to match the level of military escalation engaged in by the potential 
attacker. Full military support was defined as the major power reciprocating the attacker's level of military escalation. ${ }^{8}$

To code the dependent variable, the case summaries of each crisis provided by Brecher and Wilkenfeld $(1988,1997)$ in their ICB data set were consulted. If sufficient detail was not presented in the case summaries, I turned to historical sources for more detailed information on the diplomatic and military actions of the major power intervenor. The distribution of values on the dependent variable was $0=200$ cases $(73.5 \%)$ and $1=72$ cases $(26.5 \%)$.

The independent variables $\left(x_{1}\right.$ to $\left.x_{10}\right)$ in the equation are as follows.

\section{$x_{1}=$ Military Balance of Target Versus Attacker}

The balance of military forces was calculated as the military capabilities of the target state compared to the total capabilities of the potential attacker (including states that intervened in support of the attacker) and target. Data were collected on the size of armed forces, military expenditures, and expenditures per soldier. ${ }^{9}$ For each component, the relative capabilities of the target were measured, and a single measure of relative capabilities was calculated by taking the average of the three individual measures. ${ }^{10}$ The composite measure of relative capabilities could vary in values from 0 to 1 , with scores approaching 1 indicating that the target was in a very strong military position, and values close to 0 indicating just the opposite.

\section{$x_{2}=$ Level of Security Threat for Target of Threat}

To measure the gravity of the security threat, I created a simple dummy variable from the 6-point gravity scale constructed by Brecher and Wilkenfeld (1988) for their ICB data set. A value of 1 was assigned to all cases in which the target faced a threat of large-scale civilian and/or military casualties in a war, military occupation, or annexation of national territory (values of 5-6 on the scale). All other levels of threat were coded as 0 (levels 1-4).

\section{$\boldsymbol{x}_{3}=$ Military Balance of Major Power and Target Versus Attacker}

For this variable, military capabilities were measured exactly as discussed above with the addition that the military capabilities of the major power intervenor and any supporting allies were added to the capabilities of the target. As a result, this variable

8. The 6-point scale of military escalation presented in Huth $(1988,67-68)$ was revised by adding an additional category of small- and large-scale (1,000 or more troops) use of military force. The highest levels of escalation for each side were then compared.

9. Data on troop levels and military expenditures were taken from the updated Correlates of War (COW) data set on national capabilities, which is available from the Interuniversity Consortium for Political and Social Research (ICPSR) at the University of Michigan.

10. When states were involved in crises that were not contiguous to their national territory, I adjusted state capabilities to take into account the impact of distance in reducing the ability of states to project their military forces (Bueno de Mesquita 1981, 105). 
measures the relative capabilities of the opposing coalitions of states that were directly involved in each of the international crises.

\section{$\boldsymbol{x}_{\mathbf{4}}=$ Major Power Armed Conflict with Other States}

For this variable, I created a scale of involvement in international armed conflict that ranged from 0 to 12, with each increment representing a doubling of the number of military forces mobilized for armed intervention or already committed to armed combat at the time of a given international crisis. ${ }^{11}$ Data on the timing and size of military forces engaged in armed conflicts were taken from Dupuy (1993), Clodfelter (1992), Bercovitch and Jackson (1997), Small and Singer (1982), and the updated COW data sets on international wars and militarized interstate disputes. ${ }^{12}$

\section{$x_{5}=$ Armed Conflict within Major Power}

This variable was coded with the same scale described above with actual values ranging from 0 to 9 . Data were collected on periods of civil war, suppression of domestic unrest, or attempted or threatened military coups either within the homeland territory of a major power or its colonial territories. The same sources as listed above were relied on with the addition of the updated COW data set on civil wars. ${ }^{13}$

\section{$x_{6}=$ Military Ties between}

\section{Major Power and Target of Threat}

The first step was to determine whether the major power had any of the following types of cooperative military ties with the target state: a military alliance, a primary supplier of military arms, or use of target territory for military bases. A simple dummy variable was then constructed, with 0 equaling no military ties and 1 equaling one or more military ties.

A military alliance included all defense pacts and ententes between a major power and target, and data were taken from the updated COW military alliance data set. The major power was coded as a primary arms supplier to the target if the major power provided more than $50 \%$ of all arms imported by the target in a 3-year period prior to the international crisis (Harkavy 1975; Sutton and Kemp 1966; U.S. Arms Control and Disarmament Agency 1975-1991). Finally, data on the location of major power military bases on the territory of target states were gathered from Harkavy (1982, 1989).

11. The scale is as follows: $0=0-1,000,1=1,001-2,500,2=2,501-5,000,3=5,001-10,000,4=$ $10,001-20,000,5=20,001-40,000,6=40,001-80,000,7=80,001-160,000,8=160,001-320,000,9=$ $320,001-640,000,10=640,001-1,280,000,11=1,280,001-2,560,000$, and $12=2,560,001-5,120,000$.

12. The COW data sets on wars and militarized disputes are summarized in Jones, Bremer, and Singer (1996) and are available from the ICPSR at the University of Michigan.

13. The COW civil war data set is available from the ICPSR at the University of Michigan. 


\section{$x_{7}=$ Common Adversary between \\ Major Power and Target of Threat}

This variable was coded as a dummy variable, where $1=$ the attacker in the crisis is a common adversary, and $0=$ the challenger is not a common adversary. A common adversary was coded as present in any of the following situations: (1) the major power and target were involved in territorial disputes with the challenger, (2) the major power and target were involved in militarized conflicts with the challenger state within 5 years of the current crisis, and (3) the challenger was providing arms and military supplies to rebels and nonstate actors who were engaged in armed conflict with the major power and target within the past 5 years. Data on territorial disputes were taken from Huth (1996), ${ }^{14}$ and information on militarized conflict involvement was taken from the updated COW militarized interstate dispute data set (Jones, Bremer, and Singer 1996) and the ICB data set. Challenger indirect military support for armed rebel activity was gathered from the case summaries of crises in the ICB data set, Toynbee (1925-1951), and Bercovitch and Jackson (1997).

\section{$x_{8}=$ Strategic Location of Target}

This variable was coded as a dummy variable, where $1=$ target was strategically located and $0=$ target was not strategically located. Strategic location was coded as including any of the following: the target was contiguous to territory on which the major power was currently fighting a war, the target was contiguous to homeland or colonial territory of the major power, and the target was contiguous to a military ally of the major power. ${ }^{15}$

\section{$x_{9}=$ Similarity of Regime \\ between Major Power and Target of Threat}

I coded whether the major power and the threatened state were jointly democratic, fascist, or communist. If both countries shared the same type of regime that also differed from the regime type of the attacker, a value of 1 was coded and 0 otherwise. The codings for democracy were based on the Polity II net democracy scores (Gurr, Jaggers, and Moore 1989), which range from -10 to +10 . I coded any country as firmly democratic with a score of +7 or greater. ${ }^{16}$ Communist regimes were coded for the Soviet Union and in the post-World War II period for China, Cuba, Vietnam, Ethiopia, Mozambique, Czechoslovakia, Yugoslavia, Poland, and Hungary (Europa Publications 1990; Delury 1987). Finally, fascist major powers in the 1930s included Germany, Italy, and Japan.

14. The data set presented in Huth originally covered the years from 1950 to 1990 but has now been extended to the years from 1919 to 1995.

15. A military ally was defined as a state that had a formal alliance with the major power or permitted a major power to have military bases on its territory.

16. Sensitivity checks were conducted with alternative thresholds of +6 and +8 , and the empirical results reported in Table 1 for this variable are robust across the different measures. 


\section{$x_{10}=$ Prospects for Victory in Upcoming Elections}

To determine prospects for victory in upcoming elections, the first step was to determine whether democratic or semidemocratic states (France, 1919-1988; United States, 1919-1988; United Kingdom, 1919-1988; Italy, 1919-1925; and Japan, 19191932) ${ }^{17}$ held elections during an international crisis or scheduled them within 3 months after the end of a crisis (Gorvin 1989; Mackie and Rose 1974; Maus 1988). The dates of elections were then matched with the ICB data set dates for each crisis. If an overlap occurred between elections and the crisis, the next step was to determine the incumbent regime's prospects in the upcoming elections. I wanted to code whether leaders believed that their party was either running behind or very close with the opposition and might lose or enjoyed a solid advantage and seemed likely to win by a comfortable margin.

For cases between 1919 and 1938, I had to rely on political histories to assess the electoral prospects of incumbent leaders and their parties in elections (Bernard and Dubief 1985; Derfler 1983; Duus 1988; Gilbert 1980; Morgan 1995; Lyttelton 1987; Mowat 1955; Ward 1968). From 1939 forward, I used Gallup and other public opinion polling data to assess how close the elections were. From the polling data, I determined that if the majority of polls conducted in the 3 months prior to the election indicated that the incumbent leader consistently enjoyed a greater than $10 \%$ margin in the polls, then I coded the incumbent as likely to win the upcoming election and not face a very close race (Craig 1989; Gallup 1972, 1976a, 1976b, 1985). A value of 1 was coded for all such cases and 0 otherwise.

\section{RESULTS OF DATA ANALYSIS}

The logit results are presented in Table 1 and provide strong support for several of the hypotheses tested. All but one of the coefficients are in the predicted direction, only one coefficient is clearly statistically insignificant, and the substantive impact of the variables ranges from moderately strong to quite large. To help interpret the substantive impact of each variable, additional tables are presented that provide information on the marginal impact of variables on the probability of major power intervention.

The first result is that the more capable the target state was of defending itself, the less likely the major power was to intervene. In Table 1 , the coefficient is negative for this variable, as predicted by hypothesis 1 , and is significant $(t$ ratio $=-3.39, p<.001$ ). The marginal impact of this variable is presented in Table 2 . The baseline case is one in which a major power has military ties with the target and the target faces a high level of security threat. As a result, there are security incentives to intervene but the target is in a very favorable military position. As the balance of military strength shifts

17. By 1926, competitive elections in Italy were no longer possible because Mussolini's regime had consolidated power and used violence to weaken political opposition (Morgan 1995, chaps. 2-3; Lyttelton 1987, chaps. 10-11). In Japan, the multiparty system began to break down in the early 1930s as the military assumed greater political control, and by 1940, the multiparty system was formally ended (Duus 1988, chap. 3). 
TABLE 1

Logit Analysis of Probability of Major Power Intervention in Crises, 1918-1988

\begin{tabular}{lccc}
\hline \hline Explanatory Variables & Coefficient & $\begin{array}{c}\text { Standard } \\
\text { Errors }\end{array}$ & $\begin{array}{c}\text { Significance } \\
\text { Level }\end{array}$ \\
\hline Corrected constant & -8.53 & 1.22 & $<.001$ \\
Military strength of target & -4.27 & 1.26 & $<.001$ \\
Gravity of security threat confronting target & 1.43 & 0.51 & $<.005$ \\
Military strength of coalition supporting target & 5.97 & 1.48 & $<.001$ \\
Military ties between target and major power & 3.08 & 0.47 & $<.001$ \\
Common adversary between target and major power & 1.86 & 0.48 & $<.001$ \\
Target is strategically located & 0.81 & 0.57 & $<.08$ \\
Involvement in international armed conflict & 0.01 & 0.06 & - \\
Involvement in domestic armed conflict & -0.16 & 0.10 & $<.06$ \\
Common political ties between target and major power & 1.62 & 0.51 & $<.001$ \\
Prospect of winning elections & -1.81 & 0.91 & $<.025$ \\
\hline
\end{tabular}

NOTE: Number of observations $=272$; initial $\log$ likelihood $=-188.54$; log likelihood at convergence $=$ -77.78 ; percentage of cases correctly predicted $=84.6$. All significance levels are based on one-tailed tests.

from a position of decided advantage (.8) to one of clear weakness for the target (.1) in equations 1 through 7 , the probability of a major power intervening increases by $60 \%$.

Of the 72 cases of military intervention, only 4 crises $(5.5 \%)$ occurred when the target had a two-to-one or greater advantage in capabilities, and in only 9 crises (about $12 \%$ ) did the major power intervene when the target's capabilities were equal to or greater than the attacker and its allies. Thus, in $88 \%$ of the military interventions by major powers, if the target had been left to its own defense, it would have been confronted by a stronger coalition of states threatening an attack. The relative military weakness of the target was close to being a necessary condition for major power military interventions. Another way to illustrate this point is to look at those 67 crises in which the target was equal to or stronger than the attacker in military strength. In only 2 cases $(3 \%)$ did a major power intervene with full military support for such relatively powerful targets.

The next hypothesis to consider is hypothesis 3 , which posited that major powers were more likely to intervene if the combined capabilities of the major power, the target, and any other allies were greater than the combined military forces of the attacker coalition. In Table 1, the coefficient for this variable is positive and significant as predicted $(t$ ratio $=4.05, p<.001$ ). In Table 3 , we start with the same baseline situation as in Table 2, but we now consider shifts in the military balance between attacker and target coalitions. As the capabilities of the coalition supporting the target shifts from a position of weakness to clear advantage (from .4 to .9) in equations 1 through 5 , the likelihood of major power intervention increases by about $55 \%$.

These two findings on the military balance indicate that although major powers were more likely to intervene in support of relatively weak targets, they were also not 


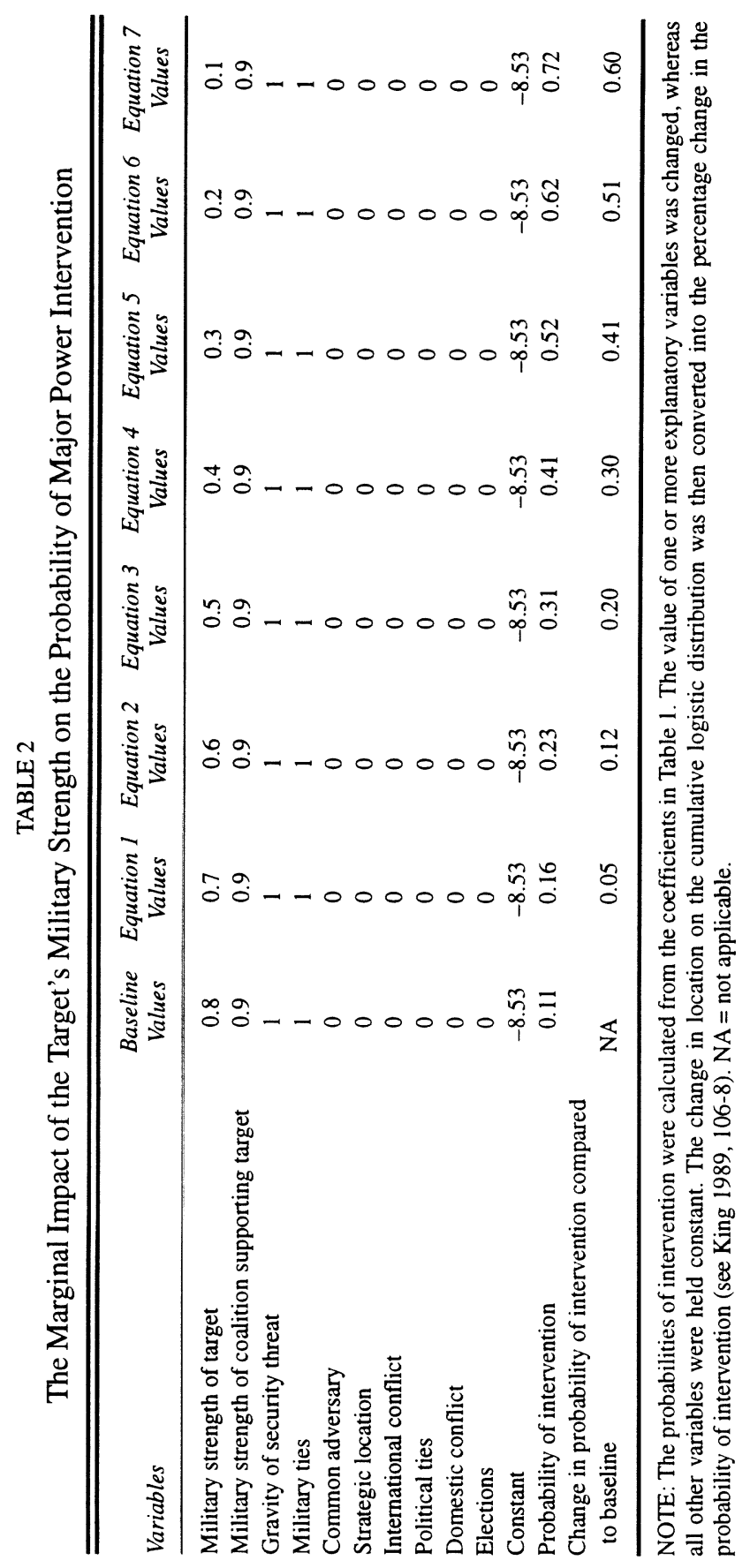




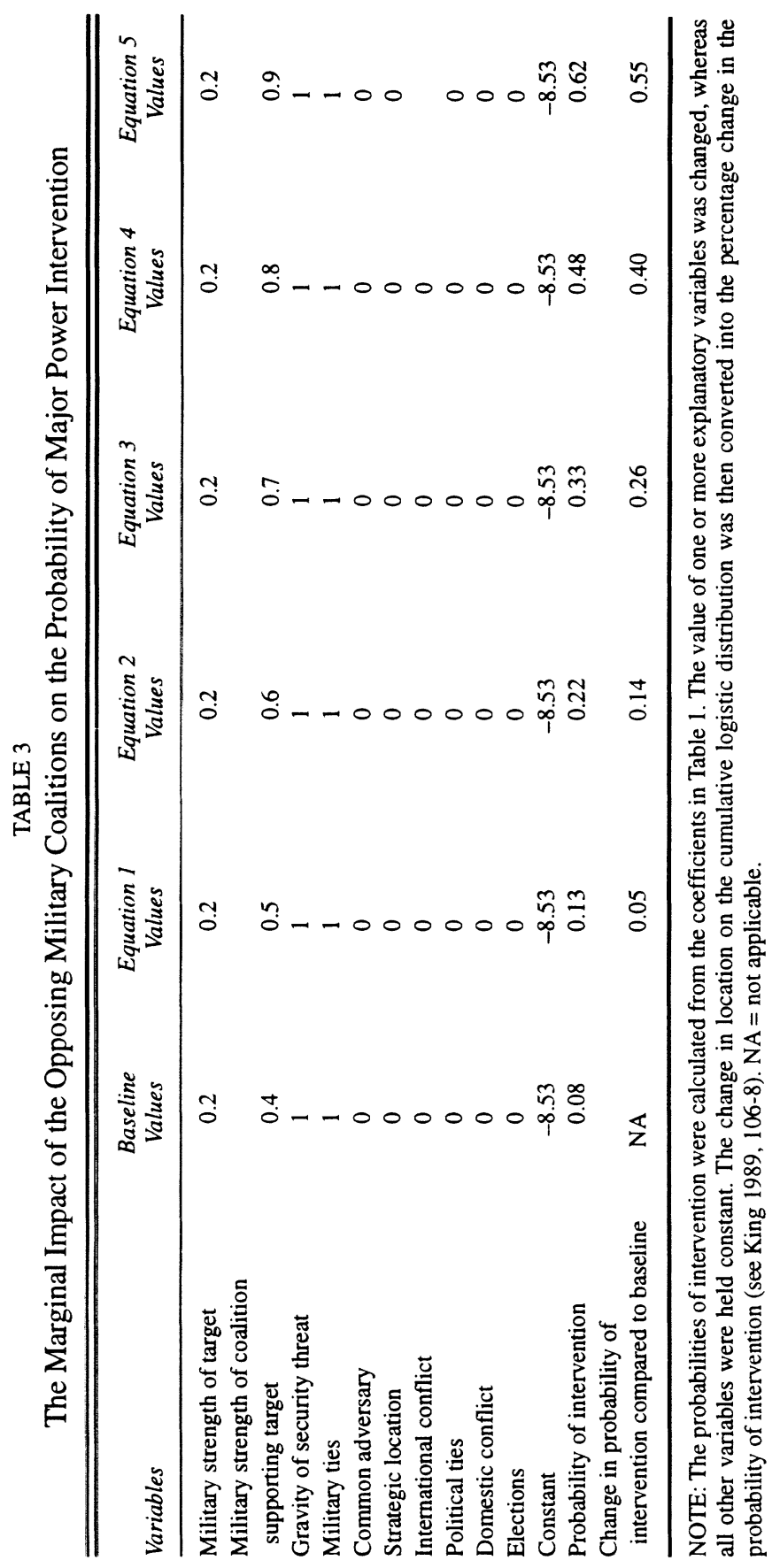


likely to intervene unless that military disadvantage could be overcome by the addition of the major power's forces and those of supporting allies. Thus, although major powers balanced against threats to target states, their willingness to oppose threats was tempered by an assessment of how risky and costly such interventions would be. Of the 72 cases of military intervention, the capabilities of the target coalition were greater than the attacker's in close to $88 \%$ of the crises (63/72). Furthermore, even in the 9 crises in which the capabilities of the target coalition were less than equal to those of the attacker, the balance of forces was still close to relative parity. There was not a single case of major power military intervention in which the major power coalition was at a decisive military disadvantage. In sum, these findings point to the conclusion that relative parity or a military advantage for the target coalition was very close to being a necessary condition for major power military intervention.

At the same time, a military advantage was clearly not a sufficient condition for major power military intervention. The coalition that might have supported the target was equal to or stronger than the attacker coalition in more than $80 \%$ of the crises $(222 / 272)$, but the major power in fact only intervened with force in about $28 \%$ of the cases (63/222). Similarly, of the 173 cases of no involvement by major powers in support of targets, $82 \%$ occurred when the major power had a military advantage (142/173). Furthermore, the major powers involvement in armed conflicts with other states had no discernable impact, contrary to hypothesis 4 . The coefficient is essentially 0 with a high standard error $(b=0.008, t$ ratio $=0.12)$. This very weak result reflects the fact that although involvement in armed conflict was associated with a low rate of intervention in crises (about 27\%), the rate of intervention was the same (about 26\%) even when the major power was not involved in any armed conflicts or at very low levels. ${ }^{18}$

The supporting results for hypotheses 1 and 3 indicate that although calculations of military advantage and risk do play an important role in decisions to intervene, by themselves they cannot provide complete explanations. As several of the other hypotheses argue, calculations of domestic and foreign policy interests at stake are essential to the analysis if we are to understand when intervention takes place.

The next set of findings focuses on the international security environment facing a major power when it decides whether to intervene. The first result is that major power intervention was more likely when a target faced a severe security threat (hypothesis 2). In Table 1 , the coefficient for this variable is positive as predicted and significant $(t$ ratio $=2.79, p<.01)$. The results in Table 1 also show that if the target is of military and security value to the major power, then intervention is more likely, as predicted by hypothesis 4 . For example, the variable that measures if the major power has military ties with the target (alliance, arms transfers, or military base rights) has a positive coefficient and is significant $(t$ ratio $=6.62, p<.001)$. Similarly, the variables measuring whether the attacker is a common adversary is positive and significant $(t$ ratio $=3.85, p<.001)$. Finally, if the target was strategically located, then interven-

18. Of the 95 cases in which the level of armed conflict involvement was coded a value of 1 or higher, major powers intervened in 26 crises $(26 / 95=27 \%)$. Of the 177 cases in which the level of armed conflict involvement was coded a value of 0 , major powers intervened in 46 crises $(46 / 177=26 \%$ ). 
tion was more likely, although the statistical significance is just below conventional levels $(t$ ratio $=1.43, p<.08)$.

In Table 4, the marginal effects of these variables are presented. The baseline scenario posits a crisis in which the military situation favors intervention by the major power, but otherwise there are no security or domestic political issues at stake that might provide reasons to intervene. Equation 1 shows that a severe threat for a target state by itself has a very limited effect because the probability of intervention increases by only $1 \%$. This suggests that even though an imminent threat of military attack establishes that another state is in need of military support, major power leaders will be very unlikely to take forceful actions unless there are military and security issues at stake in supporting that threatened state. Thus, equations 2 through 4 indicate that the combination of a clear threat to the target and a target that is of military and security value to the major power on one dimension produces an increase in major power intervention, ranging from $3 \%$ to $25 \%$. Much stronger effects are present, however, when the target's military and security importance can be coded as present along two different dimensions. Thus, in equations 5 through 7 , the probabilities of major power intervention increase from $18 \%$ to $68 \%$.

Of the three indicators of the target's military and security value to the major power, the presence of direct cooperative military ties in the form of alliance obligations, military base rights, or an arms supplier relationship seem to have the largest impact. ${ }^{19}$ Among the related set of equations 2 through 4, the largest marginal effect occurs when such ties are present. Similarly, in the next set of equations (5-7), the largest marginal effect occurs when these military ties exist, and the smallest marginal effect is produced when such ties are absent. In the data set, there are 185 crises in which the major power had no military ties with the target; in only 17 cases $(9 \%)$, the major power intervened with limited or full military force. In contrast, in the 87 crises in which the major power had one or more military ties with the target, the rate of military intervention was about $63 \%$ (55/87), which is a sevenfold increase in the rate of intervention. Another way of illustrating the importance of cooperative military ties is to note that of the 173 crises in which the major power did not intervene with any diplomatic or military support, there were only 4 cases $(2 \%)$ in which the major power had multiple military ties. Put differently, the presence of multiple ties was quite close to being a necessary condition for nonintervention by the major power.

The final set of results in Table 1 focus on how domestic political incentives influence decisions to intervene. The first finding is that major powers were more likely to intervene if the target and major power shared the same type of political regime, whereas the attacker's regime type differed from these two states. As proposed by hypothesis 7 , the coefficient for this variable is positive and significant $(t$ ratio $=$

19. These results converge with my findings in previous work (Huth and Russett 1988; Huth 1994). In addition, these results parallel those of Altfeld and Bueno de Mesquita (1979), who find that states with similar alliance partners are more likely to be on the same side in wars. Meernik (1994) also finds that the use of force by U.S. presidents is more likely if the United States has military base rights and provides military arms to the state that is threatened. Finally, Kaw $(1989,1990)$ also found that the Soviet Union was most likely to intervene in support of states that had alliance or arms transfer ties with the Soviet Union. 


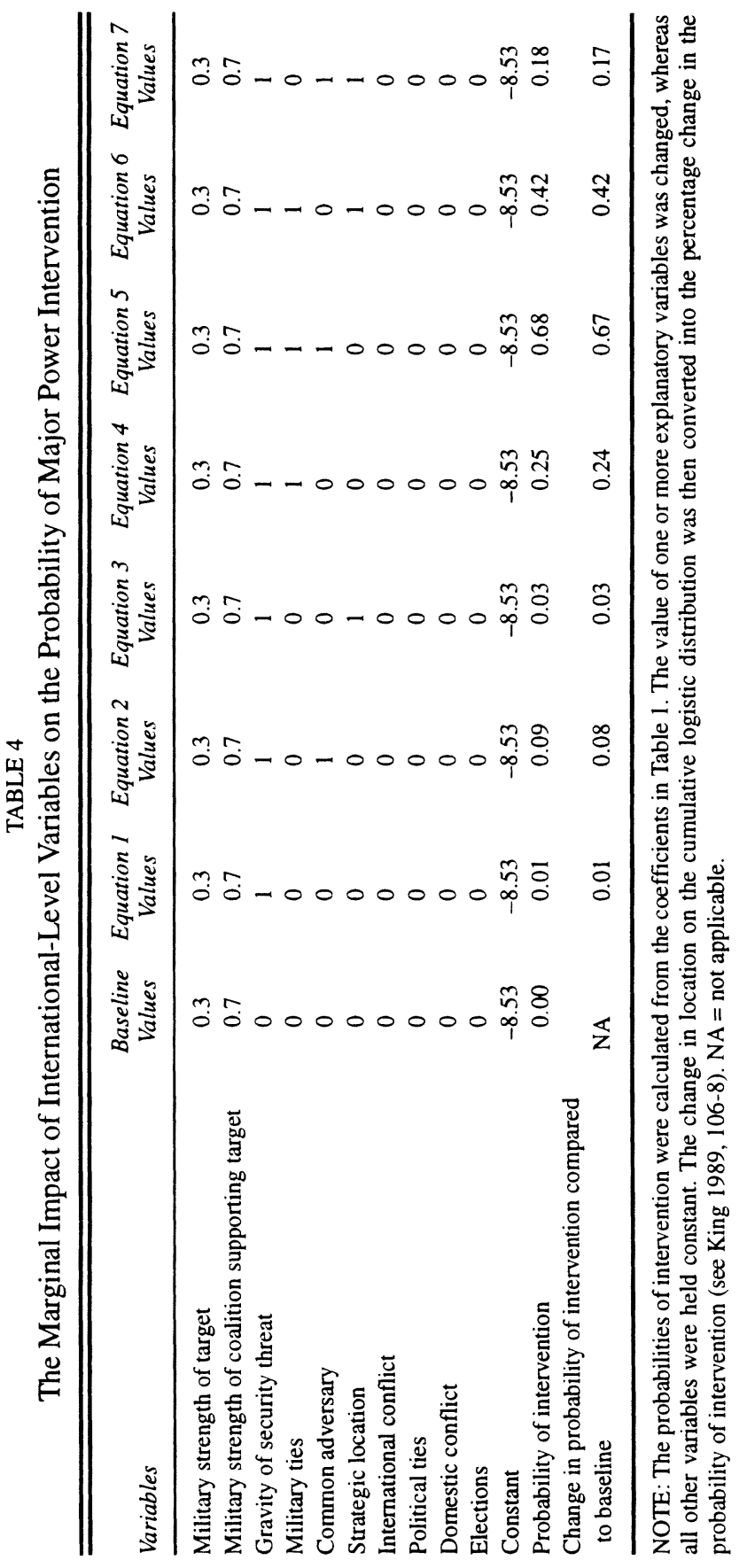


$3.18, p<.001)$. In the data set, there are 20 cases of military intervention by major powers that shared common political ties with target states. All but 3 involved democratic major powers intervening in support of democratic target states. The other cases involved the Soviet Union supporting communist countries. Although the hypothesis as stated implies that leaders from communist, fascist, or democratic states would be more likely to intervene on the grounds of common political ties with target states, the actual data set consists largely of major powers and targets that shared common democratic ties. Of the 48 cases in which the similarity of regime variable was coded as present, 45 (94\%) involved democratic states, and the remaining 3 cases involved communist countries. The results can be generalized only to the behavior of democratic major powers.

The next finding in Table 1 centers on the impact of elections. If political leaders were likely to win upcoming elections, then intervention was less likely, as predicted by hypothesis 8 . The coefficient for this variable is negative and significant $(t$ ratio $=$ $-1.99, p<.025){ }^{20}$ The final result to report is that if the leaders of major powers had committed armed forces to the suppression of domestic political opposition within their own country or that of colonial territories, the likelihood of military intervention decreased, as proposed by hypothesis 5 (although the level of statistical significance falls just below conventional thresholds; $t$ ratio $=1.55, p<.06$ ).

The marginal effects for these variables are reported in Table 5. The baseline case establishes a crisis in which the military situation favors intervention, the target faces a high threat, and the major power has cooperative military ties with the target. Equation 1 shows that if the target and major power are political allies, the likelihood of intervention increases by $38 \%$. These marginal impact results provide support for the argument that a common political ideology acts as an important political force in shaping foreign policy leaders' conceptions of what security interests are at stake in international crises. The political incentives to support a democratic ally were balanced carefully by the leaders of democratic major powers against the international security interests at stake and the military risks of taking forceful action. Overall, democratic major powers intervened to support democratic targets in only about $38 \%$ of the cases in which the two states were both democratic (17/45). Furthermore, the results in equations 8 through 10 suggest that the prospects of victory in upcoming elections effectively counterbalance the incentive to intervene in support of political allies. For example, in equation 8 , the combination of common political ties and a likely victory in upcoming elections produces a net decrease of $3 \%$ in the likelihood of intervention. In equation 9, however, despite moderate levels of domestic armed conflict, the

20. These results on elections help to refine existing findings regarding the relationship between elections and the use of military force. Several studies have reported that proximity to elections increases the chances that the United States will resort to military actions short of war in international disputes (Wang 1996; Ostrom and Job 1986; James and Oneal 1991; Russett 1990; Stoll 1984). The results reported here suggest that such risk-acceptant behavior is likely to occur when presidents or prime ministers are involved in tight competitive elections. Conversely, another study of elections and war involvement reports that democratic states are less likely to become involved in war as elections approach (Gaubatz 1991). Such risk-averse behavior, however, should be particularly prevalent when political leaders have a firm lead in the polls and are confident of victory in upcoming elections. The larger implication is that previous studies may have overstated the generality of a positive or negative empirical relationship between elections and the use of force. 


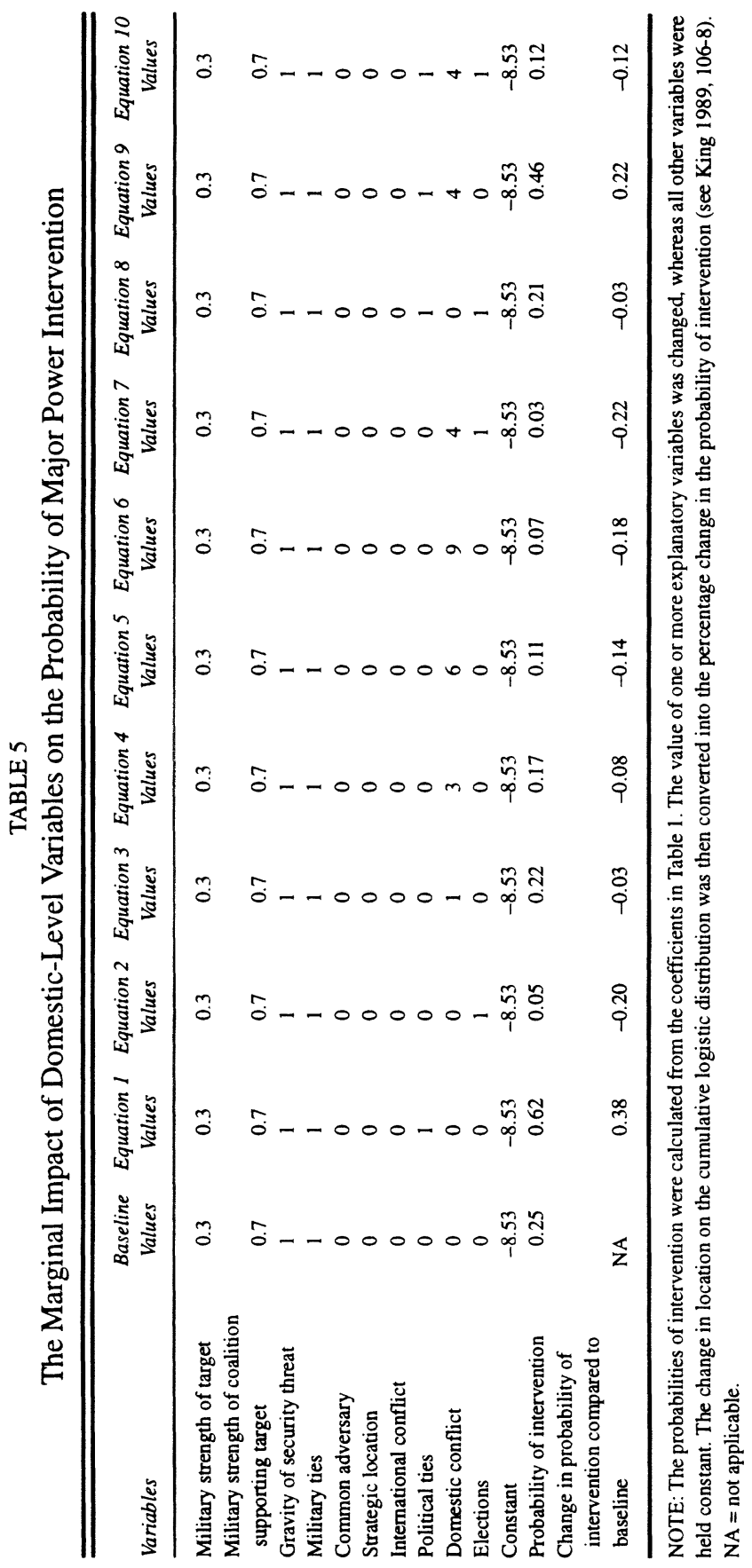


chances of intervention increase by $22 \%$, but in equation 10 , the prospect of victory in elections seems critical in driving down the chances of intervention by $12 \% .^{21}$

Equations 2 through 7 focus on domestic conditions that reduce the incentives for intervention. In equation 2 , incumbent leaders who stand a very good chance of reelection are $20 \%$ less likely to intervene, but in equations 3 through 6 , the change from low to high levels of domestic armed conflict produces a maximum decrease of $18 \%$ in the likelihood of intervention. In equation 7 , the presence of both a likely victory in elections and a moderate level of domestic armed conflict produces a negative change in the likelihood of intervention by $22 \%$.

\section{CONCLUSION}

Building on the findings of this article, three areas seem promising for future research. First, research is needed to test arguments about how leaders package decisions to intervene to build a coalition of domestic support and counter opposition (e.g., Nincic 1997). Similarly, research is required to determine when political opposition challenges leaders on decisions to intervene and whether the ability of leaders to manage such opposition depends on the issues at stake and arguments about military risks.

Second, research could be conducted to assess the deterrent value of military ties between states in preventing challenger states from initiating crises. For example, the findings on military ties between major powers and target states provide interesting clues about selection effects and the deterrent value of military ties between states. About $70 \%$ of all the crises (185/272) involved attackers challenging a target state that had no observable military ties with a major power, but only about $11 \%$ of all the crises (30/272) involved targets that had multiple military ties with a major power. This would suggest that states lacking military ties with major powers are much more likely to be the target of military threats, and such ties contribute to an effective policy of general extended deterrence. A more direct test would require a larger data set of international disputes in which only a subset escalated to the point of becoming international crises. With this larger data set, one could test whether targets in disputes without military ties to major powers were more likely to become targets in crises. If the results of such a test were to confirm that alliances and other military ties were correlated with a lower likelihood of crisis involvement, then we would have an interesting pair of findings in the empirical literature. That is, although military ties are not very effective for promoting extended immediate deterrence (Huth 1988), they

21. These findings are relevant to the debate about whether democratic states are particularly likely to form alliances or align with each other. Siverson and Emmons (1991) present evidence that democratic states are more likely to form alliances with one another in the 20th century. Werner and Lemke (1997) also report that the military balance did not play a strong role in decisions by democratic states to intervene in disputes in support of other democratic states. Simon and Gartzke (1996) and Walt (1987), however, argue that common political ties are not a powerful cause of alignment choices. My findings lead me to take a middle ground and argue that the desire to support a democratic ally is unlikely to prevail if the international security context is unfavorable or if it introduces short-term domestic political risks for leaders at a sensitive time in the electoral cycle. 
would be much more effective for promoting extended general deterrence. Such findings would be consistent with selection effect arguments as applied to deterrence and alliances (Fearon 1994b; Smith 1996a).

The third area for future research is the effectiveness of major power interventions in deterring challengers related to regime type. Are interventions by democratic states more successful due to the greater credibility of crisis military actions that are undertaken by leaders who face higher domestic audience costs (Fearon 1994a; see also Reiter and Stam 1998)? This line of research would broaden the debate about what factors shape the credibility of threats by carefully testing the importance of domestic political institutions and processes.

\section{REFERENCES}

Agresti, A. 1990. Categorical data analysis. New York: John Wiley.

Aldrich, J., J. Sullivan, and E. Borgida. 1989. Foreign affairs and issue voting. American Political Science Review 83:123-42.

Altfeld, M., and B. Bueno de Mesquita. 1979. Choosing sides in war. International Studies Quarterly 23:87-112.

Bercovitch, J., and R. Jackson. 1997. International conflict management from 1945 to 1995. Washington, DC: Congressional Quarterly Books.

Bernard, P., and H. Dubief. 1985. The decline of the Third Republic 1914-1938. Cambridge, UK: Cambridge University Press.

Brace, P., and B. Hinckley. 1992. Follow the leader. New York: Basic Books.

Brecher, M., and J. Wilkenfeld. 1988. Crises in the twentieth century. Vol. 1. New York: Pergamon. 1997. A study of crisis. Ann Arbor: University of Michigan Press.

Brody, R. 1991. Assessing the president. Stanford, CA: Stanford University Press.

Bueno de Mesquita, B. 1981. The war trap. New Haven, CT: Yale University Press.

Bueno de Mesquita, B., and D. Lalman. 1990. Domestic opposition and foreign war. American Political Science Review 84:747-66.

Bueno de Mesquita, B., and R. Siverson. 1995. War and the survival of political leaders. American Political Science Review 89:841-55.

1997. Nasty or nice? Political systems, endogenous norms, and the treatment of adversaries. Journal of Conflict Resolution 41:175-99.

Bueno de Mesquita, B., R. Siverson, and G. Woller. 1992. War and the fate of regimes. American Political Science Review 86:638-46.

Clodfelter, M. 1992. Warfare and armed conflicts. Vol. 2. London: McFarland.

Craig, F.W.S., ed. 1989. British electoral facts 1832-1987. London: Parliamentary Research Services.

Delury, G., ed. 1987. World encyclopedia of political systems and parties. 2 vols., 2nd ed. New York: Facts on File Publications.

Derfler, L. 1983. President and parliament. Boca Raton: University Presses of Florida.

Downs, G., and D. Rocke. 1995. Optimal imperfection. Princeton, NJ: Princeton University Press.

Dupuy, E. R. 1993. The Harper encyclopedia of military history. 4th ed. New York: HarperCollins.

Duus, P., ed. 1988. The Cambridge history of Japan. Vol. 6. Cambridge, UK: Cambridge University Press.

Europa Publications. 1990. The Europa world yearbook 1990. 2 vols. London: Europa Publications.

Fearon, J. 1994a. Domestic political audiences and international disputes. American Political Science Review 88:577-92.

. 1994b. Signaling versus the balance of power and interests. Journal of Conflict Resolution 38:236-69.

1997. Signaling foreign policy interests. Journal of Conflict Resolution 41:68-90. 
Fleiss, J. 1981. Statistical methods for rates and proportions. New York: John Wiley.

Freedman, L., and E. Karsh. 1993. The Gulf conflict. Princeton, NJ: Princeton University Press.

Freeman, C. W. 1998. Preventing war in the Taiwan Strait. Foreign Affairs 77:6-11.

Gallup, G. 1972. The Gallup Poll: Public opinion 1935-1971. Vol. 1. New York: Random House.

1976a. The Gallup international public opinion polls: Great Britain 1937-1975. 2 vols. New York: Random House.

1976b. The Gallup international public opinion polls: France 1939, 1944-1975. New York: Random House.

1985. The Gallup Poll: Public opinion 1984. Wilmington, DE: Scholarly Resources.

Gartner, S., and R. Siverson. 1996. War expansion and war outcomes. Journal of Conflict Resolution 40:4-15.

Gasiorowski, M. 1995. Economic crisis and political regime change. American Political Science Review 89:882-97.

Gaubatz, K. T. 1991. Election cycles and war. Journal of Conflict Resolution 35:212-44.

Gilbert, B. 1980. Britain since 1918. 2nd rev. ed. New York: St. Martin's.

Gorvin, I., ed. 1989. Elections since 1945. London: Longman.

Gow, J. 1997. Triumph of the lack of will. New York: Columbia University Press.

Gowa, J. 1998. Parties, voters, and the use of force abroad. International Organization 52:307-24.

Gurr, T. R., K. Jaggers, and W. Moore. 1989. Polity II Codebook. Boulder: Center for Comparative Politics, Department of Political Science, University of Colorado at Boulder.

Hagan, J. 1993. Political opposition and foreign policy in comparative perspective. Boulder, CO: Lynne Rienner.

Harkavy, R. 1975. The arms trade and international systems. Cambridge, UK: Ballinger.

1982. Great power competition for overseas bases. New York: Pergamon. 1989. Bases abroad. London: Oxford University Press.

Huth, P. 1988. Extended deterrence and the prevention of war. New Haven, CT: Yale University Press. 1994. When do states take on extended deterrent commitments? In Reconstructing realpolitik, edited by F. Wayman and P. Diehl, 81-100. Ann Arbor: University of Michigan Press.

-1996. Standing your ground. Ann Arbor: University of Michigan Press.

Huth, P., and B. Russett. 1988. Deterrence failure and crisis escalation. International Studies Quarterly 32:29-46.

James, P., and J. Oneal. 1991. The influence of domestic and international politics on the president's use of force. Journal of Conflict Resolution 35:307-32.

Jones, D. 1994. Balancing and bandwagoning in militarized interstate disputes. In Reconstructing realpoli$t i k$, edited by F. Wayman and P. Diehl, 227-46. Ann Arbor: University of Michigan Press.

Jones, D., S. Bremer, and J. D. Singer. 1996. Militarized interstate disputes, 1816-1992. International Interactions 15:163-213.

Kaw, M. 1989. Predicting Soviet military intervention. Journal of Conflict Resolution 33:402-29.

1990. Choosing sides. American Journal of Political Science 34:441-70.

King, G. 1989. Unifying political methodology. Cambridge, UK: Cambridge University Press.

Levy, J. 1983. War and the modern great power system. Lexington: University of Kentucky Press.

Lian, B., and J. Oneal. 1993. Presidents, the use of military force, and public opinion. Journal of Conflict Resolution 37:277-300.

Lyttelton, A. 1987. The seizure of power. 2d ed. Princeton, NJ: Princeton University Press.

Mackie, T., and R. Rose. 1974. The international almanac of electoral history. New York: Macmillan.

Marra, R., C. Ostrom, and D. Simon. 1990. Foreign policy and presidential popularity. Journal of Conflict Resolution 34:588-623.

Maus, D., ed. 1988. Les Grands Textes de la Pratique Institutionnelle de la V Republique. Paris: La Documentation Francaise.

Meernik, J. 1994. Presidential decision making and the political use of military force. International Studies Quarterly 38:121-38.

Morgan, P. 1995. Italian fascism, 1919-1945. New York: St. Martin's.

Morgan, T. C., and K. Bickers. 1992. Domestic discontent and the external use of force. Journal of Conflict Resolution 36:25-52. 
Morrow, J. 1993. Arms versus allies. International Organization 47:263-98.

Mousseau, M. 1997. Democracy and militarized interstate collaboration. Journal of Peace Research 34:73-88.

Mowat, C. 1955. Britain between the wars. London: Methuen.

Mueller, J. 1994. Policy and opinion in the Gulf War. Chicago: University of Chicago Press.

Nincic, M. 1997. Loss aversion and the domestic context of military intervention. Political Research Quarterly 50:97-120.

Nincic, M., and B. Hinckley. 1991. Foreign policy and the evaluation of presidential candidates. Journal of Conflict Resolution 35:333-55.

Oneal, J., and B. Russett. 1997. The classical liberals were right. International Studies Quarterly 41:267-94.

Ostrom, C., and B. Job. 1986. The president and the political use of force. American Political Science Review 80:541-66.

Przeworski, A., M. Alvarez, J. A. Cheibub, and F. Limongi. 1996. What makes democracies endure? Journal of Democracy 7:39-55.

Reiter, D., and A. Stam. 1998. Democracy, war initiation, and victory. American Political Science Review 92:377-90.

Richards, D., T. C. Morgan, R. Wilson, V. Schwebach, and G. Young. 1993. Good times, bad times, and the diversionary use of force. Journal of Conflict Resolution 37:504-35.

Rousseau, D., C. Gelpi, D. Reiter, and P. Huth. 1996. Assessing the dyadic nature of democratic peace, 1918-1988. American Political Science Review 90:512-33.

Russett, B. 1990. Controlling the sword. Cambridge, MA: Harvard University Press.

Simon, M., and E. Gartzke. 1996. Do democracies flock together, or do opposites attract? Journal of Conflict Resolution 40:617-35.

Siverson, R., and J. Emmons. 1991. Birds of feather. Journal of Conflict Resolution 35:285-306.

Siverson, R., and H. Starr. 1991. The diffusion of war. Ann Arbor: University of Michigan Press.

Small, M., and J. D. Singer. 1982. Resort to arms. Beverly Hills, CA: Sage.

Smith, A. 1996a. To intervene or not to intervene. Journal of Conflict Resolution 40:16-40.

- 1996b. Diversionary foreign policy in democratic systems. International Studies Quarterly 40:133-54.

Smith, A., and D. Hayes. 1997. The shadow of the polls. International Interactions 23:79-108.

Stam, A. 1996. Win, lose, or draw. Ann Arbor: University of Michigan Press.

Stoll, R. 1984. The guns of November. Journal of Conflict Resolution 28:231-46.

Sutton, J., and G. Kemp. 1996. Arms to developing Countries, 1945-1965. London: International Institute for Strategic Studies.

Toynbee, A. 1925-1951. Survey of international affairs 1920-1939. London: Oxford University Press.

U.S. Arms Control and Disarmament Agency. 1975-1991. World military expenditures and arms transfers 1963-1990. Washington, DC: Government Printing Office.

Walt, S. 1987. The origins of alliances. Ithaca, NY: Cornell University Press.

Wang, K., and J. L. Ray. 1994. Beginners and winners. International Studies Quarterly 38:139-54.

Ward, R., ed. 1968. Political development in modern Japan. Princeton, NJ: Princeton University Press.

Werner, S. 1996. Absolute and limited war. International Interactions 22:67-88.

Werner, S., and D. Lemke. 1997. Opposites do not attract. International Studies Quarterly 41:529-46. 